UDC $576+577$

\title{
Exosomes: messengers and mediators of tumor-stromal interactions
}

\author{
K. A. Shkarina ${ }^{1,2}$, O. V. Cherednyk ${ }^{1}$, I. I. Voloschenko ${ }^{3}$, O. M. Trembach ${ }^{3}$, \\ I. O. Trembach ${ }^{3}$, A. I. Khoruzhenko ${ }^{1}$ \\ ${ }^{1}$ Institute of Molecular Biology and Genetics, NAS of Ukraine \\ 150, Akademika Zabolotnoho Str., Kyiv, Ukraine, 03680 \\ ${ }^{2}$ Educational and Scientific Center «Institute of Biology» \\ Taras Shevchenko National University of Kiev \\ 64/13, Volodymyrska Str., Kyiv, Ukraine, 01601 \\ ${ }^{3}$ JSC «Institute of Beauty» \\ 9a, Bohdana Khmel'nytskoho Str., Kyiv, Ukraine, 01030 \\ a.i.khoruzhenko@imbg.org.ua
}

\begin{abstract}
Intercellular communication is one of the most important factors involved in the maintenance of tissue homeostasis. The alteration of intercellular interaction correlates with a lot of human diseases including cancerogenesis. There are several types of such interconnection. First of all, it is a direct cell-cell contact, as it takes place in epithelium. The disturbance of this communication is expressed as a loss of cell-cell, cell-matrix contacts, disturbances of cell polarity etc. Another way of intercellular interaction involves mutual influence via paracrine factors produced by corresponding cells. However, there is another kind of information exchange between the cells, namely microvesicular transportation. It was revealed that the exosomes take part in intercellular communication in normal tissues as well as in malignant neoplasia. The present review provides the recent information on the formation of exosomes, their composition and especially the exosome participation in tumor-stromal interactions.
\end{abstract}

Keywords: exosome, tumor-stromal interaction

Introduction. The tumor development is a complex multistage process that is extremely dependent on intensive bidirectional communication between the cancer cells and their microenvironment. Stroma has generally been considered as one of the major regulators of epithelial homeostasis, and at the early stages of malignant transformation it displays a capability to inhibit or even reverse the growth of the transformed cells [1]. However, the further development of a tumor leads to complex alterations in its microenvironment, loss of its ability to support normal epithelial architecture and function, and emergence of tumor-promoting characteristics [2]. Such alterations are not restricted to the primary tumor sites; they are also shown to be an important component of the successful metastasis establishment. Fibroblasts, that represent the major cellular component of the epithelial

(C) Institute of Molecular Biology and Genetics, NAS of Ukraine, 2014 stroma, act as a leading force of these tumor-associated changes $[3,4]$.

Bidirectional crosstalk between the tumor and the surrounding stromal cells is achieved through the number of mechanisms that include the changes in chemical and physical characteristics of intercellular matrix, direct intercellular interactions and secretion of paracrine molecules and vesicles. These vesicles convey complex molecular messages between the tumor cells and host organism [5]. Exosomes are recently recognized as one of the crucial mediators of the tumor-host communication and therefore can be viewed as both a potential target and a prospective tool for anticancer therapy.

Exosomes as mediators of intercellular communication. Vesicular transport of biomolecules is a phenomenon that has been observed in different species, ranging from prokaryotes and lower eukaryotes to the complex multicellular organisms, including mammals. 
Eukaryotic cells produce several types of microvesicules with distinct biochemical and functional characteristics [6]. Exosomes represent a subset of secreted extracellular vesicles $30-100 \mathrm{~nm}$ in diameter, with characteristic spherical morphology and representative biomolecular composition. These characteristic features, together with the specific biogenesis pathway, serve as a basis for distinguishing them from other types of secreted vesicles [7]. According to numerous investigations, the majority of eukaryotic cells are capable of the exosome production both in vivo and in vitro. This type of vesicles can also be isolated from all the body fluids and secretes, including blood and lymph, amniotic, bronchoalveolar lavage and cerebrospinal fluids, saliva, urine and breast milk, as well as from the conditioned cell culture media.

Exosome composition. Exosomes produced by different cell types display significant variability in their macromolecular composition, that can also change due to the physiological state and age of the donor cell, as well as in response to certain internal and external factors [7]. Additionally, it has been suggested that a single cell could possibly produce several distinct subpopulations of exosomes with different macromolecular content and functions [8].

Lipidomic studies reveal a rather conservative lipid composition of exosomal membrane and its enrichment in lipid raft domains, saturated phospholipids and cholesterol, as well as in some other lipid types, that ensure its additional stiffness and stability $[9,10]$. Exosomes, produced by the certain types of immune cells, have been shown to contain prostaglandins and leukotriens together with enzymes involved in their biogenesis, that suggests their possible involvement in certain immune reactions [11].

Extensive proteomic analysis of exosomes reveals the presence of a wide variety of membrane-associated and cytoplasmic proteins, typical for the cell of origin. The most common components of exosomal membrane are tetraspanins (CD9, CD63, CD81 and CD82) - small tetradomain transmembrane proteins that are thought to participate in biogenesis and specific internalization of exosomes [12]. Additionally, the exosomal membrane contains the components of antigen presentation system (major histocompatibility complex, MHCI and MHCII), multiple adhesion molecules, integrins and receptors, including receptor tyrosine kinases and G-protein coupled receptors (GPCRs), components of wingless-related integration site (Wnt) and Notch signaling pathways. The internal lumen of these vesicles contains the proteins involved in the exosomal biogenesis, such as annexin, Tsg101, Rab27, Alix and syntenin-1, heat shock proteins (HSP) and shaperones (HSP60, HSP70 and HSP90), cytoskeletal proteins, metabolic enzymes and signaling pathways components [9]. Although a large part of the exosomal proteins is rather conservative due the mechanisms of their biogenesis and functional properties, the proteome also reflects the key molecular features of the cell of origin, defined by its tissue type and functional characteristics.

The exosomal membrane carries a conservative set of glycoproteins involved into intercellular adhesion and specific interactions of these vesicles with the recipient cells. The glycoprotein signature of exosomes is poorly investigated, but resent studies show the presence of polylactosamines, syaloglycoproteins and complex branched N- [13]. High rate of the exosomal surface glycosylation leads to the suggestion that glycoproteins may possibly participate in specific sorting of surface molecules into exosomes $[13,14]$.

The discovery of exosomal RNA and, later, DNA, led to a revision of the traditional understanding of intercellular communication and emergence of a concept of exosomal «shuttle» of nucleic acids [15]. Subsequent investigations demonstrate that exosomes contain a large amount of functional mRNAs and microRNAs, as well as a significant amount of tRNA, vault RNAs and other non-coding RNA species $[8,15]$. It also has been shown that after uptake the exosomal mRNAs can be effectively translated and are able to cause metabolic changes and epigenetic reprogramming of the recipient cells [16]. The recent data confirm also the presence of doublestrand fragments of nuclear and mitochondrial DNA, retrotransposones and amplified oncogene sequences in exosomes; though, the potential function of such exosomal DNA remains to be uncovered [17-19].

Exosome biogenesis. A specific mechanism of biogenesis is a characteristic feature of exosomes that clearly distinguishes them from other types of secreted microvesicles. The initial formation of late endosomes (also termed as multivesicular bodies) is a result of inward budding of primary endosome membrane, that 


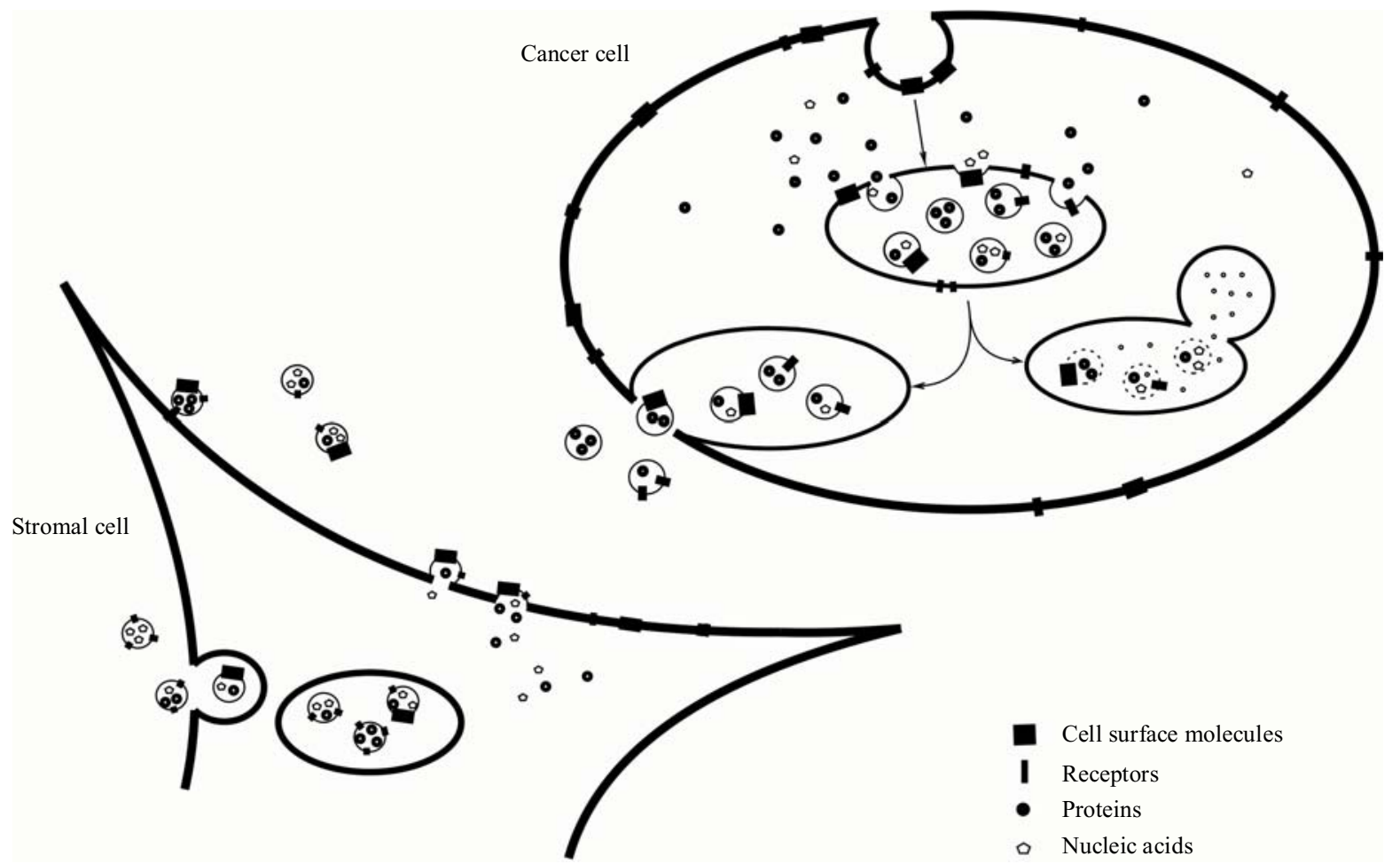

General scheme of exosome biogenesis, secretion and interaction with the recipient cell

causes the formation of multiple intraluminal vesicles. This process is generally mediated by Endosomal Complex Required for Transport (ESCRT) and additional proteins, involved in multivesicular body transport, docking and fusion with the cellular membrane [8]. Fusion of the late endosomes with the outer cellular membrane is a well-described phenomenon that results in the release of the vesicles that are now termed as exosomes (Figure). However, there is an experimental evidence demonstrating that the formation of multivesicular bodies can also proceed independently from ESCRT, suggesting the existence of alternative mechanisms of their biogenesis[20].

The difference in molecular composition of the exosomes and the cellular cytoplasm suggest a possible existence of the specific sorting mechanisms of their components [8]. It has been shown that the targeting of proteins into exosomes does not require any special sequences, but often involves certain post-translational modifications, such as ubiquitinilation and SUMOylation, as well as phosphorylation and glycosylation of particular amino acid residues [21]. Other proposed mechanisms involve the membrane protein oligomerisation, and their inclusion into lipid rafts and tetraspanin-rich domains [12, 22]. The mechanisms of RNA targeting are also poorly understood. Several recent experiments have indicated that RNA sorting requires the presence of specific sequences (25-nucleotide «Zip-codes» for mRNA and special motifs in miRNA) in their composition and is realized through the interactions with several types of heterogenic nuclear ribonucleoproteins and miRNAs $[8,23,24]$. Some miRNAs may interact with the components of ESCRT and, therefore, be sorted into multivesicular bodies for lysosomal degradation or extracellular release [25]. One of the recent studies provides the evidence that miRNA sorting might be modulated by the internal target RNA concentration, therefore serving also as the possible way of regulating intracellular RNA homeostasis [26].

However, the exact mechanisms underlying the specific sorting of exosomal content, remain a subject for future investigations.

Secretion of exosomes can proceed in a constitutive or a stimuli-dependent manner. Its rate depends on the number of factors and can vary according to the physiological state of the donor cell, cell cycle stage, cellular senescence, and in response to the stress and external stimulation $[27,28]$. Such external stimuli include chan- 
ges in macromolecular and physico-mechanic properties of extracellular matrix, a significant decrease in extracellular $\mathrm{pH}$, hypoxia, membrane depolarization (for the certain cell types), treatment of the cell with ATP, cytokines and growth factors, etc. [29].

Interaction with the recipient cells. Exosomes act as mediators of intercellular communication by transporting a variety of internal and surface-associated molecules and ligands. In extracellular space, they are recognized and captured by different types of cells. This ability of exosomes to be specifically recognized and processed by the cells depends on specific sialiglycoproteins and proteoglycans, adhesion molecules, integrins and tetraspanins in different combinations, which are present on the exosomal surface $[12,14]$.

The interaction of exosomes with the recipient cells can proceed in several ways (Figure). Some types of ligands, associated with the exosomal surface, can be recognized by cellular transmembrane receptors [30]. Several experiments suggest the possibility of direct fusion of the exosomal membrane with the outer cellular membrane; however, this process requires the match in fluidity of both participating membranes and therefore is restricted primarily to low $\mathrm{pH}$ conditions, such as those observed in the hypoxic solid tumors [31].

The mechanisms of exosome internalization are shown to be cell-type dependent and can proceed through phagocytosis, macropinocytosis or multiple types of endocytosis, including clathrin-, caveolin- and dynamindependent mechanisms [8]. The further fate of internalized exosomes is poorly investigated; according to the recent data, they can be transported to the lysosomal compartment, where their membrane undergoes degradation [32]. Other investigations demonstrate that exosomes can also accumulate inside multivesicular bodies of the recipient cell, suggesting the dual role of these organelles in exosomal metabolism [10].

The pleiotropic effect of exosomes is mediated by a wide range of signaling molecules, enzymes and different kinds of functional nucleic acids that can alter the cellular metabolism and gene expression pattern of the recipient cell. Upon exosome internalization and processing, active forms of signaling molecules and enzymes can be involved into a variety of intracellular processes. Furthermore, recent investigations have revealed an important role of exosomal mRNAs and micro
RNAs in wide post-transcriptional regulation of the gene expression in recipient cells [16][33].

Function of exosomes in normal and pathological conditions. According to the predominant conception of early investigations, exosomes served as a cellular «waste bin» and functioned mainly to remove obsolete and defective protein molecules from the cell [34]. However, the extensive investigations of the exosome structure and function, conducted during the last 15 years, shed the light on their participation in many physiological and pathological processes, which depends on the intercellular communication and signaling.

This type of microvesicles is produced by the majority of immune cells, including dendritic cells, T- and Blymphocytes, eosinophils, macrophages and mast cells. In the immune system, they are involved in antigen presentation and immune synapse establishment, immune response regulation, negative selection of T-cells in thymus and regulatory T-cells formation [35]. Cytotoxic Tlymphocytes are shown to produce the exosomes carrying certain cell death-initiating molecules, particularly Fas ligand and Tumor Necrosis Factor-related apoptosis-inducing ligand (TRAIL) on their membranes. After uptake, these exosomes are capable of initiating programmed death of transformed cells, thus conducting anti-tumor immune defense [36]. In nervous system, exosomes are produced by both neurons and different types of glia and participate in regulation of the central nervous system development, neuro-glial communication and glia differentiation, synaptic activity of neurons [37]. Some data show that they might have neuroprotective and pro-regeneratory activity $[38,39]$. In reproductive system, exosomes are apparently involved in regulation of certain aspects of gametogenesis, fertilization and implantation, as well as in establishment of dense interactions between a fetus and a mother organism [40-42].

Progression of many diseases is associated with the alterations in intercellular communication system, leading to the general perturbation of organism homeostasis. Exosomes are shown to be important players in inflammation, development of some cardiovascular diseases, hypercholesterinemia, diabetes and obesity, and neurodegenerative conditions, including multiple sclerosis development, Alzgeimer's and Parkinson's diseases [43-45]. Pathogenesis of several infectious diseases, cau- 
sed by some viruses, mycobacteria and protozoa, also depends on the exosome secretion [46]. A role of exosomes in this case can be either pro-immunogenic or immunesuppressive, depending on the nature of pathogen [35]. For example, the macrophages, infected with non-pathogenic strain of mycobacteria, release exosomes bearing bacterial antigens and promoting immune response; at the same time, exosomes, associated with the pathogenic strain infection, inhibit macrophage activation and cytokine secretion, thus diminishing immune response $[47,48]$. Some human viruses, including HIV and Epstein-Barr virus (EVB), utilize exosomal pathway for spreading among the cells and immune evasion [49, 50].

For example, the cells infected with EBV, release exosomes, containing some signaling and viral proteins and miRNA [51, 52]. Following the intake, these exosomes can activate the mitogen-activated protein kinase (MAPK) and PI3K/Akt signaling pathways, leading to increased proliferation of recipient cells, associated with the oncogenic effect of the virus [52].

Several studies revealed also unexpected function of exosomes in spreading prion proteins, thus participating in the progression of the prion-associated neurodegenerative processes [53].

Exosomes in oncogenesis. The establishment and progression of a malignant tumor are extremely dependent on its interactions with surrounding tissues, as well as on its ability to influence distant tissues and organs [54]. According to the data accumulated during the last 1.5 decades of research, exosomes are shown to play an important role in all the stages of oncogenesis. They participate in regulation of antitumor immunity, angiogenesis, tumor-stroma interactions, invasion and premetastatic niche formation [55].

Exosomes in tumor microenvironment regulation. In tumor microenvironment, exosomes are actively produced by both normal and malignant cells and participate in establishment of complex regulatory networks between tumor and the adjacent tissues. Malignant cells release higher amounts of exosomes than non-malignant cells; the quantity of exosomes produced by the cell directly correlates with the rate of its aggressiveness [56].

Following the release into extracellular environment, exosomes either interact with the same cell in autocrine manner or can be captured and internalized by the adjacent malignant and non-malignant cells. Exosomal exchange inside the malignant cell population can inhibit pro-apoptotic signaling and stimulate proliferation through PI3K/Akt and MAPK/ERK signaling pathways [57]. Exchange of proteins and RNA between different subpopulations of tumor cells has also been recognized as an important factor in transfer of malignant phenotypic features from more aggressive cells to less aggressive [58]. This kind of communication accounts for extracellular exchange of oncogenic proteins. For example, such transfer of mutant form of epidermal growth factor receptor (EGFRvIII) to the cells previously lacking it leads to initiation of anti-apoptotic protein expression and increased proliferation [59]. Similar mechanisms are employed in the exchange of mutant forms of K-RAS protein in colon carcinoma cells [11]. Some cancer cells secrete exosomes with high quantities of survavin, an apoptosis inhibitor, and therefore facilitate the survival of other cells in population [60].

It has been suggested that exosomes play a crucial role in establishing and spreading chemoresistance inside the tumor cell population. Some anticancer drugs have been shown to affect the rate of extracellular vesicle release. Several chemotherapeutic drugs, such as cisplatin and doxorubicin, can be actively released from the cell through the incorporation into exosomes [61, 62]. Strikingly, some kinds of chemoresistance are the subject for intercellular transfer. For example, the exosomes, released from the drug-resistant cancer cells, can transfer a multidrug transporter P-glycoprotein to the drug-sensitive cells [63]. The same mechanisms of active export are also described for some important antiapoptotic regulators, including PTEN [64].

Exosomes as regulators of aggressive behavior of cancer cells. Hypoxia is one of the common features of solid tumor microenvironment. According to several experiments, it leads to the stimulation of production of increased quantities of the tumor cell exosomes, that, in turn, are capable of stimulation of angiogenesis and invasiveness $[65,66]$. A decrease of extracellular $\mathrm{pH}$, associated with the low oxygen concentration, also favors an active intake of exosomes by surrounding transformed cells and stroma [65]. Microvesicles, produced by the hypoxic cancer cells, contain the increased amounts of cytokines, growth factors and certain types of miRNAs, as well as surface-associated ligands, that together sti- 
mulate the pro-angiogenic response inside surrounding tissue [67]. For example, incorporation of vesicles with VEGF by endoteliocytes leads to the activation of Akt and MAPK pathways and expression of VEGFR [68]. The colon cancer derived exosomes contain the mRNA of cell cycle regulators that after intake in endoteliocytes and translation significantly stimulate their proliferation [69]. Other exosomal ligands, such as Deltalike-4, inhibit division of endoteliocytes in vitro, but at the same time increase their migratory activity [70]. Taken altogether, these findings suggest for the major pro-angiogenic functions of tumor exosomes.

One of the most dangerous features of the malignant behavior of cancer cells is their invasiveness, or ability to penetrate the basal membrane barriers and invade into surrounding tissues. The proteolysis-dependent invasion requires the formation of invadopodia - three-dimensional membrane protrusions that participate in degradation of extracellular matrix components and facilitate cancer cell migration into surrounding stroma. Resent investigation shows that ability of the cancer cell to generate invadopodia displays direct correlation with the rate of exosomal secretion. Invadopodia contain the multiple multivesicular bodies docking sites that promote the exosome release into extracellular environment. The release of exosomes, in turn, triggers the formation of new invadopodia, thus establishing a positive feedback loop [56].

Highly invasive cells also produce the exosomes enriched in membrane-associated forms of the matrix metalloproteinases, such as MMP2, MMP9 and urokinase plasminogen activator, as well as in HSP, particularly HSP90, that can also activate the extracellular endopeptidases, therefore facilitating the matrix degradation [71, 72].

Tumor exosomes in immunity modulation. Tumor cell exosomes have been shown to interact with immune system, causing both pro-immunogenic and anti-immunogenic effects. Under normal conditions, they are recognized and processed by the different types of antigen-presenting cells, and trigger antitumor immunity. However, this mechanism can be hijacked by tumor cells. The malignant cells are shown to produce exosomes with altered functions and composition, that instead of triggering a cytotoxic immune response modulate and suppress antitumor immunity. For example, they can impede the activation of dendritic and T-cells and initiate the suppressor and regulatory $\mathrm{T}$-cell generation. Regulatory T-cells, in turn, suppress cytotoxic T-cells that normally conduct a anti-tumor response [73] [74]. The exosomes carrying Faso can also directly induce apoptosis of the CD8-positive T-cell [74].

Exosomes in tumor-stroma interactions. The tumorstroma interactions are currently recognized as an important factor in ontogenesis progression that significantly affect the tumor cells signaling, survival and proliferation, as well as modulate their invasive properties and drug sensitivity. Certain primary alterations in tumor stroma may lead to an increased risk of the tumor development [75]. For example, a loss of PTEN expression in stromal fibroblasts is associated with a higher risk of the breast tumor development. At the same time, the normal expression of this gene is necessary for the maintenance of normal epithelial homeostasis [76].

Bidirectional communication between stroma and cancer cells is achieved through a number of mechanisms, such as establishment of direct intercellular junctions and extracellular matrix alterations, as well as by secretion of some paracrine ligands and microvesicles. Numerous investigations confirm the fact that the exchange of exosomes between malignant and stromal cells takes place both in vitro and in vivo [77]. Some of the well-recognized mediators of tumor-stroma communication, such as transforming growth factor $\beta$ (TGF $\beta)$ and members of Wnt family, are present in tumor microenvironment in both soluble form and in association with the outer exosomal membrane $[78,79]$.

TGF $\beta$ is one of the most recognized factors involved in tumor to stroma signaling and fibroblast activation. During the normal wound healing process, epithelial cells produce TGF $\beta 1$-containing exosomes, that are able to activate adjacent stromal fibroblasts, thus creating favorable conditions for epithelial regeneration [80]. The activation of carcinoma-associated fibroblasts (CAFs) is a representative feature of tumor stroma, and is underlain by the same mechanisms. According to the literature data, the exosomes bearing TGF $\beta$ can cause an activation of normal fibroblasts, as well as initiate the differentiation of mesenchymal stem cells and adipocytes into myofibroblast-like cells [78, 81-83]. Certain research findings support the conclusion that the vesicular rather than the soluble form of TGF $\beta 1$ has pro-on- 
cogenic activating effect on fibroblasts. Such effect is possibly mediated by additional ligands on the surface of exosomes, particularly by the heparansulphate chains that can significantly affect the internal signal transduction pathways [78].

The activated fibroblasts at the tumor growth sites carry out numerous tumor-supportive activities, secreting large quantities of growth factors and cytokines, participating in external matrix proteolysis and remodeling, recruiting endotheliocytes, macrophages and mesenchymal stem cells [4]. Among other factors, they produce large quantities of exosome-anchored Wnt, that normally serves as an important mediator of cell polarity and locomotion in embryogenesis and in adult tissues [84]. During the tumor development, Wnt acts as a positive regulator of locomotion activity and invasiveness of malignant cells. According to the recent data, the exosomes bearing a membrane-anchored form of Wnt activate the planar cell polarity (PCP) pathway in the breast cancer cells and increase their motility, and therefore promote the invasion and metastasis [85]. Taken together, these findings reveal a previously unknown mechanism of the tumor-stroma interactions via exosomes and point on the crucial role these vesicles may play in the tumor establishment and progression. However, the exact nature and mechanisms underlying this phenomenon remains the subject for further investigations.

Clinical significance of tumor-derived exosomes. Macromolecular composition of exosomes closely mimics the key molecular features of the donor cell, and therefore can serve as a potential source of information about its physiological state and the gene expression profile. Tumor cells secrete increased amount of extracellular vesicles, comparing to non-malignant cells, and these vesicles can be identified in the majority of biological fluids, laying the basis for new diagnostic strategies. Tumor exosomes contain large quantities of tumorspecific proteins and nucleic acids. Some miRNAs are specifically expressed in transformed cells and can be found in their exosomes [86]. Since they do not undergo extracellular nuclease degradation, these RNAs can be detected during the long period and in relatively low concentrations. This seems especially valuable in case of malignancies that usually difficult to identify during the early stages of their development [7]. Exosomes may also be used for determination of the most efficient com- bination of drugs and assessment of therapeutic effect in the course of treatment [87].

Due to their important role in oncogenesis, exosomes are seriously considered as a potential target for novel anti-tumor therapies [88]. For example, in experiments the inhibition of exosome secretion can suppress the cancer cell proliferation and metastatic capabilities; but the real clinical value of such inhibitors is rather unclear. Another proposed therapeutic approach for advanced-stage cancer treatment implies the total clearance of the patient's blood from all the exosomes with HER2 antibodies [89]. Some strategies require therapeutic blockage of the exosome production by malignant and host cells by targeting exosome biogenesis pathway, or preventing their uptake by recipient cells.

Ubiquitousness and physiological relevance of exosomes make them a promising next-generation drug delivery system for targeted therapy of cancer [90]. They may be implied as the vectors for a specific transport of certain proteins, oncosupressor mRNAs and miRNAs, as well as artificial chemotherapeutic compounds [91, 92]. The major advantages of exosomes, comparing to other vector systems, are their non-imunogenic properties, high stability under physiological conditions, and existence of the natural mechanisms of specific recognition and internalization [93]. This makes them an attractive tool for developing the field of RNA medicine, where the creation of effective delivery system is one of the major problems [94]. However, though there is a growing number of proposed implications of exosomes in clinical oncology, they remain primarily theoretic, and there is currently no approved treatment strategy or diagnostic tools employing this type of vesicles. Further investigations are required to ensure safe and effective application of exosomes for the cancer therapy.

Conclusions. The emerging conception of intercellular vesicular transport of biomolecules challenges the traditional understanding of mechanism of intercellular communication in eukaryotic organisms. The recent advances in exosome research shed light on the significant role of this type of secreted microvesicles in a wide range of physiological and pathological processes. However, the exact nature of the mechanisms of exosome production and interactions with the recipient cells, as well as many of their functions in norma and pathology, still remain rather unclear. A detailed investigation 
of exosomes, as well as other microvesicles and mediators, in cancer, and tumor-stroma communications in particular, might bring a new understanding of mechanisms that underlie malignant transformation and tumor progression, and lead to optimization of current oncological diagnostic and therapeutic methods.

Екзосоми як посередники пухлино-стромальних взаємодій

Шкаріна К. А., Чередник О. В., Волощенко I. I., Трембач О. М., Трембач I. O., Хоруженко А. I.

\section{Резюме}

Міжклітинні комунікаиії є одним з найважливіших факторів, які беруть участь у підтримиі тканинного гомеостазу. Порушення міжклітинних взаємодій корелює з великою кількістю захворювань, серед яких канцерогенез. Існує кілька типів міжклітинних взаємодій. Насамперед, ие безпосередній контакт клітина-клітина, щзо характерно для епітелія. Збій такої міжклітинної взаємодії має наслідком втрату міжклітинних контактів, контактів клітина-матрикс, порушення клітинної полярності і т. д. Іниий спосіб міжклітинної взаємодї полягає у взаємному впливові, опосередкованому паракринними чинниками, які продукуються відповідними клітинами. Однак є ще один тип обміну інформацією між клітинами, а саме -мікровезикулярний транспорт. Встановлено, що мікровезикули екзосом беруть участь у взаємодії клітин у нормальних тканинах, а також у злоякісних новоутвореннях. Представлений огляд надає сучасну інформацію щуодо формування екзосом, їхнього складу $і$, особливо, їхньої причетності до пухлино-стромальних взаємодій.

Ключові слова: екзосоми, пухлино-стромальна взаємодія.

Экзосомы как посредники опухолево-стромальных взаимодействий

Шкарина Е. А., Чередник О. В., Волощенко И. И., Трембач А. М., Трембач И. А., Хоруженко А. И.

Резюме

Межклеточные коммуникации являются одним из наиболее важных факторов, участвующих в поддержании тканевого гомеостаза. Нарушение межклеточных взаимодействий коррелирует с большим количеством заболеваний, включая канцерогенез. Существует несколько типов межклеточных взаимодействий. Прежде всего, это непосредственный контакт клетка-клетка, что характерно для эпителия. Сбой такого межклеточного взаимодействия выражается в потере межклеточных контактов, контактов клетка-матрикс, в нарушении клеточной полярности и т. д. Другой способ межклеточного взаимодействия заключается во взаимовлиянии, опосредованном паракринными факторами, продуцируемыми соответствующими клетками. Однако существует еще один тип обмена информацией между клетками, а именно - микровезикулярный транспорт. Установлено, что микровезикуль экзосом участвуют во взаимодействии клеток в нормальных тканях, а также в злокачественных новообразованиях. Настоящиий обзор предоставляет современную информачию о формировании экзосом, их составе и, особенно, об их причастности к опухолево-стромальным взаимодействиям.

Ключевые слова: экзосомы, опухолево-стромальное взаимодействие.

\section{REFERENCES}

1. Mueller MM, Fusenig NE. Friends or foes - bipolar effects of the tumour stroma in cancer. Nat Rev Cancer. 2004;4(11):839-49.

2. Quail DF, Joyce JA. Microenvironmental regulation of tumor progression and metastasis. Nat Med. 2013;19(11):1423-37.

3. Erez N, Truitt M, Olson P, Arron ST, Hanahan D. Cancer-associated fibroblasts are activated in incipient neoplasia to orchestrate tumor-promoting inflammation in an NF-kappaB-dependent manner. Cancer Cell. 2010;17(2):135-47.

4. Kalluri R, Zeisberg M. Fibroblasts in cancer. Nat Rev Cancer. 2006;6(5):392-401.

5. Rak J. Extracellular vesicles - biomarkers and effectors of the cellular interactome in cancer. Front Pharmacol. 2013;4:21.

6. van der Pol E, Boing AN, Harrison P, Sturk A, Nieuwland R. Classification, functions, and clinical relevance of extracellular vesicles. Pharmacol Rev. 2012;64(3):676-705.

7. Vlassov AV, Magdaleno S, Setterquist R, Conrad R. Exosomes: current knowledge of their composition, biological functions, and diagnostic and therapeutic potentials. Biochim Biophys Acta. 2012;1820(7):940-8.

8. Villarroya-Beltri C, Baixauli F, Gutierrez-Vazquez C, SanchezMadrid F, Mittelbrunn M. Sorting it out: Regulation of exosome loading. Semin Cancer Biol. 2014;28C:3-13.

9. Choi DS, Kim DK, Kim YK, Gho YS. Proteomics, transcriptomics and lipidomics of exosomes and ectosomes. Proteomics. 2013;13(10-11):1554-71.

10. Subra $C$, Laulagnier $K$, Perret B, Record $M$. Exosome lipidomics unravels lipid sorting at the level of multivesicular bodies. Biochimie. 2007;89(2):205-12.

11. Subra C, Grand D, Laulagnier K, et al. Exosomes account for vesicle-mediated transcellular transport of activatable phospholipases and prostaglandins. J Lipid Res. 2010;51(8):2105-20.

12. Rana S, Yue S, Stadel D, Zoller M. Toward tailored exosomes: the exosomal tetraspanin web contributes to target cell selection. Int J Biochem Cell Biol. 2012;44(9):1574-84.

13. Batista BS, Eng WS, Pilobello KT, Hendricks-Munoz KD, Mahal $L K$. Identification of a conserved glycan signature for microvesicles. J Proteome Res. 2011;10(10):4624-33.

14. Escrevente C, Grammel N, Kandzia $S$, et al. Sialoglycoproteins and N-glycans from secreted exosomes of ovarian carcinoma cells. PLoS One. 2013;8(10):e78631.

15. Valadi H, Ekstrom K, Bossios A, Sjostrand M, Lee JJ, Lotvall JO. Exosome-mediated transfer of mRNAs and microRNAs is a novel mechanism of genetic exchange between cells. Nat Cell Biol. 2007;9(6):654-9.

16. Ramachandran $S$, Palanisamy $V$. Horizontal transfer of RNAs: exosomes as mediators of intercellular communication. Wiley Interdiscip Rev RNA. 2012;3(2):286-93.

17. Kahlert C, Melo SA, Protopopov A, et al. Identification of double-stranded genomic DNA spanning all chromosomes with mutated KRAS and p53 DNA in the serum exosomes of patients with pancreatic cancer. J Biol Chem. 2014;289(7):3869-75.

18. Thakur BK, Zhang H, Becker A, et al. Double-stranded DNA in exosomes: a novel biomarker in cancer detection. Cell Res. 2014; 24(6):766-9.

19. Balaj L, Lessard R, Dai L, et al. Tumour microvesicles contain retrotransposon elements and amplified oncogene sequences. Nat Commun. 2011;2:180.

20. Alonso R, Mazzeo C, Rodriguez MC, et al. Diacylglycerol kinase $\alpha$ regulates the formation and polarisation of mature multivesicular bodies involved in the secretion of Fas ligand-containing exosomes in T lymphocytes. Cell Death Differ. 2011;18(7): $1161-73$. 
21. Moreno-Gonzalo O, Villarroya-Beltri C, Sanchez-Madrid F. Posttranslational modifications of exosomal proteins. Front Immunol. 2014;5:383.

22. de Gassart A, Geminard C, Fevrier B, Raposo G, Vidal M. Lipid raft-associated protein sorting in exosomes. Blood. 2003;102 (13):4336-44

23. Bolukbasi MF, Mizrak A, Ozdener GB, et al. miR-1289 and «zipcode»-like sequence enrich mRNAs in microvesicles. Mol Ther Nucleic Acids. 2012;1:e10.

24. Villarroya-Beltri C, Gutierrez-Vazquez C, Sanchez-Cabo F, et al. Sumoylated hnRNPA2B1 controls the sorting of miRNAs into exosomes through binding to specific motifs. Nat Commun. 2013;4:2980.

25. Gibbings DJ, Ciaudo C, Erhardt M, Voinnet $O$. Multivesicular bodies associate with components of miRNA effector complexes and modulate miRNA activity. Nat Cell Biol. 2009;11 (9):1143-9.

26. Squadrito ML, Baer C, Burdet F, et al. Endogenous RNAs modulate microRNA sorting to exosomes and transfer to acceptor cells. Cell Rep. 2014;8(5):1432-46.

27. Lehmann BD, Paine MS, Brooks AM, et al. Senescence-associated exosome release from human prostate cancer cells. Cancer Res. 2008;68(19):7864-71.

28. Zoller M. Pancreatic cancer diagnosis by free and exosomal miRNA. World J Gastrointest Pathophysiol. 2013;4(4):74-90.

29. Urbanelli L, Magini A, Buratta $S$, et al. Signaling pathways in exosomes biogenesis, secretion and fate. Genes (Basel). 2013;4 (2): $152-70$

30. Stenqvist AC, Nagaeva O, Baranov V, Mincheva-Nilsson L. Exosomes secreted by human placenta carry functional Fas ligand and TRAIL molecules and convey apoptosis in activated immune cells, suggesting exosome-mediated immune privilege of the fetus. J Immunol. 2013;191(11):5515-23.

31. Parolini I, Federici C, Raggi C, et al. Microenvironmental $\mathrm{pH}$ is a key factor for exosome traffic in tumor cells. J Biol Chem. 2009; 284(49):34211-22.

32. Tian T, Zhu YL, Hu FH, Wang YY, Huang NP, Xiao ZD. Dynamics of exosome internalization and trafficking. J Cell Physiol. 2013;228(7):1487-95.

33. Camussi $G$, Deregibus MC, Bruno S, Grange C, Fonsato V, Tetta $C$. Exosome/microvesicle-mediated epigenetic reprogramming of cells. Am J Cancer Res. 2011;1(1):98-110.

34. Stoorvogel W, Kleijmeer MJ, Geuze HJ, Raposo G. The biogenesis and functions of exosomes. Traffic. 2002;3(5):321-30.

35. Robbins PD, Morelli AE. Regulation of immune responses by extracellular vesicles. Nat Rev Immunol. 2014;14(3):195-208.

36. Fais $S$. NK cell-released exosomes: Natural nanobullets against tumors. Oncoimmunology. 2013;2(1):e22337.

37. Chivet $M$, Hemming F, Pernet-Gallay $K$, Fraboulet $S$, Sadoul R. Emerging role of neuronal exosomes in the central nervous system. Front Physiol. 2012;3:145.

38. Ghidoni R, Paterlini A, Albertini V, et al. Cystatin C is released in association with exosomes: a new tool of neuronal communication which is unbalanced in Alzheimer's disease. Neurobiol Aging. 2011;32(8):1435-42.

39. Fruhbeis C, Frohlich D, Kramer-Albers EM. Emerging roles of exosomes in neuron-glia communication. Front Physiol. 2012; 3:119.

40. Harada Y, Yoshida K, Kawano N, Miyado K. Critical role of exosomes in sperm-egg fusion and virus-induced cell-cell fusion. Reprod Med Biol. 2013; 12(4):117-26.

41. Kshirsagar SK, Alam SM, Jasti S, et al. Immunomodulatory molecules are released from the first trimester and term placenta via exosomes. Placenta. 2012;33(12):982-90.
42. Mincheva-Nilsson L, Baranov $V$. The role of placental exosomes in reproduction. Am J Reprod Immunol. 2010;63(6):520-33.

43. Rome $S$. Are extracellular microRNAs involved in type 2 diabetes and related pathologies? Clin Biochem. 2013;46(10-11): 937-45.

44. Gaceb A, Martinez MC, Andriantsitohaina R. Extracellular vesicles: new players in cardiovascular diseases. Int J Biochem Cell Biol. 2014;50:24-8.

45. Russo I, Bubacco L, Greggio E. Exosomes-associated neurodegeneration and progression of Parkinson's disease. Am J Neurodegener Dis. 2012;1(3):217-25.

46. Silverman JM, Reiner NE. Exosomes and other microvesicles in infection biology: organelles with unanticipated phenotypes. Cell Microbiol. 2011;13(1):1-9.

47. Singh PP, Smith VL, Karakousis PC, Schorey JS. Exosomes isolated from mycobacteria-infected mice or cultured macrophages can recruit and activate immune cells in vitro and in vivo. J Immunol. 2012;189(2):777-85.

48. Singh PP, LeMaire C, Tan JC, Zeng E, Schorey JS. Exosomes released from $M$. tuberculosis infected cells can suppress IFN- $\gamma$ mediated activation of naive macrophages. PLoS One. 2011;6 (4):e18564.

49. Izquierdo-Useros N, Naranjo-Gomez M, Erkizia I, et al. HIV and mature dendritic cells: Trojan exosomes riding the Trojan horse? PLoS Pathog. 2010;6(3):e1000740.

50. Wurdinger T, Gatson NN, Balaj L, Kaur B, Breakefield XO, Pegtel $D M$. Extracellular vesicles and their convergence with viral pathways. Adv Virol. 2012;2012:767694.

51. Dergai OV, Dergai MV, Skrypkina IYa, Tsyba LO, Yaruchik AM, Rynditch $A V$. Amphiphysin 1 and 2 interact with latent membrane protein $2 \mathrm{~A}$ of Epstein-Barr virus and regulate its exosomal secretion. Biopolym Cell. 2012;28(3):234-8.

52. Meckes DG Jr, Shair KH, Marquitz AR, Kung CP, Edwards RH, $R a a b-T r a u b N$. Human tumor virus utilizes exosomes for intercellular communication. Proc Natl Acad Sci U S A. 2010;107 (47):20370-5.

53. Coleman BM, Hanssen E, Lawson VA, Hill AF. Prion-infected cells regulate the release of exosomes with distinct ultrastructural features. FASEB J. 2012;26(10):4160-73.

54. Pietras $K$, Ostman A. Hallmarks of cancer: interactions with the tumor stroma. Exp Cell Res. 2010;316(8):1324-31.

55. Ono M, Kosaka N, Tominaga N, et al. Exosomes from bone marrow mesenchymal stem cells contain a microRNA that promotes dormancy in metastatic breast cancer cells. Sci Signal. 2014; 7(332):ra63

56. Hoshino D, Kirkbride KC, Costello K, et al. Exosome secretion is enhanced by invadopodia and drives invasive behavior. Cell Rep 2013;5(5):1159-68

57. Yang L, Wu XH, Wang D, Luo CL, Chen LX. Bladder cancer cellderived exosomes inhibit tumor cell apoptosis and induce cell proliferation in vitro. Mol Med Rep. 2013;8(4):1272-8.

58. Hao $\mathrm{S}, \mathrm{Ye} \mathrm{Z}, \mathrm{Li}$ F, et al. Epigenetic transfer of metastatic activity by uptake of highly metastatic B16 melanoma cell-released exosomes. Exp Oncol. 2006;28(2):126-31.

59. Sanderson MP, Keller S, Alonso A, Riedle S, Dempsey PJ, Altevogt $P$. Generation of novel, secreted epidermal growth factor receptor (EGFR/ErbB1) isoforms via metalloprotease-dependent ectodomain shedding and exosome secretion. J Cell Biochem. 2008;103(6): 1783-97.

60. Khan S, Jutzy JM, Aspe JR, McGregor DW, Neidigh JW, Wall $N R$. Survivin is released from cancer cells via exosomes. Apoptosis. 2011;16(1):1-12.

61. Safaei R, Larson BJ, Cheng TC, et al. Abnormal lysosomal trafficking and enhanced exosomal export of cisplatin in drug-resis- 
tant human ovarian carcinoma cells. Mol Cancer Ther. 2005; 4(10): 1595-604.

62. Chen VY, Posada MM, Blazer LL, Zhao T, Rosania GR. The role of the VPS4A-exosome pathway in the intrinsic egress route of a DNA-binding anticancer drug. Pharm Res. 2006;23(8):1687-95.

63. Ambudkar SV, Sauna ZE, Gottesman MM, Szakacs G. A novel way to spread drug resistance in tumor cells: functional intercellular transfer of P-glycoprotein (ABCB1). Trends Pharmacol Sci. 2005;26(8):385-7.

64. Hopkins BD, Fine B, Steinbach N, et al. A secreted PTEN phosphatase that enters cells to alter signaling and survival. Science. 2013;341(6144):399-402.

65. King HW, Michael MZ, Gleadle JM. Hypoxic enhancement of exosome release by breast cancer cells. BMC Cancer. 2012;12: 421.

66. Ramteke A, Ting H, Agarwal C, et al. Exosomes secreted under hypoxia enhance invasiveness and stemness of prostate cancer cells by targeting adherens junction molecules. Mol Carcinog. 2013. Dec 17. doi: $10.1002 / \mathrm{mc} .22124$. [Epub ahead of print].

67. Park JE, Tan HS, Datta A, et al. Hypoxic tumor cell modulates its microenvironment to enhance angiogenic and metastatic potential by secretion of proteins and exosomes. Mol Cell Proteomics. 2010;9(6):1085-99.

68. Al-Nedawi K, Meehan B, Kerbel RS, Allison AC, RakJ. Endothelial expression of autocrine VEGF upon the uptake of tumor-derived microvesicles containing oncogenic EGFR. Proc Natl Acad Sci U S A. 2009;106(10):3794-9.

69. Kahlert C, Kalluri R. Exosomes in tumor microenvironment influence cancer progression and metastasis. J Mol Med (Berl). 2013; 91(4):431-7.

70. Sharghi-Namini S, Tan E, Ong LL, Ge R, Asada HH. Dll4-containing exosomes induce capillary sprout retraction in a 3D microenvironment. Sci Rep. 2014;4:4031.

71. van Doormaal FF, Kleinjan A, Di Nisio M, Buller HR, Nieuwland $R$. Cell-derived microvesicles and cancer. Neth J Med. 2009;67 (7):266-73.

72. Shimoda M, Khokha R. Proteolytic factors in exosomes. Proteomics. 2013;13(10-11):1624-36.

73. Xiang X, Poliakov A, Liu C, et al. Induction of myeloid-derived suppressor cells by tumor exosomes. Int J Cancer. 2009;124 (11):2621-33.

74. Taylor DD, Gercel-Taylor C. Exosomes/microvesicles: mediators of cancer-associated immunosuppressive microenvironments. Semin Immunopathol. 2011;33(5):441-54.

75. Bhowmick NA, Neilson EG, Moses HL. Stromal fibroblasts in cancer initiation and progression. Nature. 2004;432(7015):332-7.

76. Trimboli AJ, Cantemir-Stone CZ, Li F, et al. Pten in stromal fibroblasts suppresses mammary epithelial tumours. Nature. 2009; 461(7267):1084-91.

77. Suetsugu A, Honma K, Saji S, Moriwaki H, Ochiya T, Hoffman $R M$. Imaging exosome transfer from breast cancer cells to stroma at metastatic sites in orthotopic nude-mouse models. Adv Drug Deliv Rev. 2013;65(3):383-90.

78. Webber JP, Spary LK, Sanders AJ, et al. Differentiation of tumour-promoting stromal myofibroblasts by cancer exosomes. Oncogene. 2014. doi: 10.1038/onc.2013.560
79. Gross JC, Chaudhary V, Bartscherer K, Boutros M. Active Wnt proteins are secreted on exosomes. Nat Cell Biol. 2012;14(10): 1036-45.

80. Borges FT, Melo SA, Ozdemir BC, et al. TGF- $\beta 1$-containing exosomes from injured epithelial cells activate fibroblasts to initiate tissue regenerative responses and fibrosis. J Am Soc Nephrol. 2013;24(3):385-92.

81. Webber J, Steadman R, Mason MD, Tabi Z, Clayton A. Cancer exosomes trigger fibroblast to myofibroblast differentiation. Cancer Res. 2010;70(23):9621-30.

82. Cho JA, Park H, Lim EH, et al. Exosomes from ovarian cancer cells induce adipose tissue-derived mesenchymal stem cells to acquire the physical and functional characteristics of tumor-supporting myofibroblasts. Gynecol Oncol. 2011;123(2):379-86.

83. Cho JA, Park H, Lim EH, Lee $K W$. Exosomes from breast cancer cells can convert adipose tissue-derived mesenchymal stem cells into myofibroblast-like cells. Int J Oncol. 2012;40(1):130-8.

84. Luga V, Wrana JL. Tumor-stroma interaction: Revealing fibroblast-secreted exosomes as potent regulators of Wnt-planar cell polarity signaling in cancer metastasis. Cancer Res. 2013;73 (23):6843-7.

85. Luga V, Zhang L, Viloria-Petit AM, et al. Exosomes mediate stromal mobilization of autocrine Wnt-PCP signaling in breast cancer cell migration. Cell. 2012;151(7):1542-56.

86. Pigati L, Yaddanapudi SC, Iyengar R, et al. Selective release of microRNA species from normal and malignant mammary epithelial cells. PLoS One. 2010;5(10):e13515.

87. Zhang $H G$, Grizzle WE. Exosomes: a novel pathway of local and distant intercellular communication that facilitates the growth and metastasis of neoplastic lesions. Am J Pathol. 2014;184(1):28-41.

88. Vader P, Breakefield XO, Wood MJ. Extracellular vesicles: emerging targets for cancer therapy. Trends Mol Med. 2014;20 (7):385-93.

89. Marleau AM, Chen CS, Joyce JA, Tullis RH. Exosome removal as a therapeutic adjuvant in cancer. $J$ Transl Med. 2012;10:134.

90. Fais S, Logozzi M, Lugini L, et al. Exosomes: the ideal nanovectors for biodelivery. Biol Chem. 2013;394(1):1-15.

91. Ohno S, Takanashi M, Sudo K, et al. Systemically injected exosomes targeted to EGFR deliver antitumor microRNA to breast cancer cells. Mol Ther. 2013;21(1):185-91.

92. Alvarez-Erviti L, Seow Y, Yin H, Betts C, Lakhal S, Wood MJ. Delivery of siRNA to the mouse brain by systemic injection of targeted exosomes. Nat Biotechnol. 2011;29(4):341-5.

93. Kooijmans SA, Vader P, van Dommelen SM, van Solinge $W W$, Schiffelers RM. Exosome mimetics: a novel class of drug delivery systems. Int $J$ Nanomedicine. 2012;7:1525-41.

94. Tan A, Rajadas J, Seifalian AM. Exosomes as nano-theranostic delivery platforms for gene therapy. Adv Drug Deliv Rev. 2013; 65(3):357-67. 